\title{
Implementation of Think Pair Share (TPS) Learning Model in civic education
}

\author{
Uswatun Khasanah \\ SDN Luwunggede 03 \\ uswatun736@gmail.com
}

\section{Article History}

accepted 14/11/2020

approved $21 / 11 / 2020$

published 26/11/2020

\begin{abstract}
The purpose of this study was to improve the learning outcomes of students in the PPKn muple in grade II elementary schools with the Think Pair Share (TPS) learning model. The research carried out was to use the Classroom Action Research (CAR) in two cycles, with each cycle consisting of one meeting. The stages of each cycle are planning, implementing, observing and reflecting. Each meeting was conducted a knowledge test by reinforcing formative tests and summative tests to determine the development of students. In the first cycle students who completed after carrying out summative tests were $68 \%$. In the second cycle the students were complete after carrying out summative tests of $84 \%$. These results indicate that the Pairing learning model (pairing pictures) can improve student learning outcomes, especially the Class II PPKn muple at SD N LUWUNGGEDE 03.
\end{abstract}

Keywords: Think pair share, learning model, elementary school

\section{Abstrak}

Tujuan dari penelitian ini adalah untuk meningkatkan hasil belajar peserta didik pada mupel PPKn di sekolah dasar kelas II dengan model pembelajaran Think Pair Share ( TPS ). Penelitian yang dilakukan adalah dengan menggunaan Penelitian Tindakan Kelas (PTK) sebanyak dua siklus, dengan setiap siklusnya terdiri dari satu pertemuan. Tahapan setiap siklusnya adalah perencanaan, pelaksanaan, observasi dan refleksi. Setiap pertemuan dilakukan uji pengetahuan dengan mengguatkan tes formatif dan tes sumatif untuk mengetahui perkembangan peserta didik. Pada siklus I peserta didik yang tuntas setelah melaksanakan tes sumatif sebesar $68 \%$. Pada siklus II peserta didik tuntas setelah melaksanakan tes sumatif sebesar $84 \%$. Hasil ini menunjukan bahwa model pembelajaran Pairing ( memasangkan gambar ) dapat meningkatkan hasil belajar peserta didik khususnya mupel PPKn Kelas II di SD N LUWUNGGEDE 03.

Kata kunci: Think pair share, model pembelajaran, sekolah dasar

Social, Humanities, and Education Studies (SHEs): Conference Series https://jurnal.uns.ac.id/shes 


\section{PENDAHULUAN}

Menurut Undang-Undang Sistem Pendidikan Nasional nomor 20 tahun 2003 dinyatakan bahwa Pendidikan nasional kita bertujuan untuk mengembangkan potensi peserta didik agar menjadi manusia yang beriman dan bertakwa kepada Tuhan Yang Maha Esa, berakhlak mulia, sehat, berilmu, cakap, kreatif, mandiri dan menjadi warga negara yang demokratis serta bertanggung jawab. Oleh karena itulah guru sebagai pelaksana utama pendidikan di sekolah diharapkan memiliki wawasan tentang mutu pembelajaran yang hendak diterapkan dalam pembelajaran di kelasnya. Langkah ini merupakan pendekatan secara langsung yang akan mendukung mutu produk atau mutu akhir pendidikan berupa lulusan yang bermutu.

Dalam upaya mencapai tujuan tersebut diatas, guru memiliki peranan yang sangat penting. Kedudukan guru dan dosen sebagai tenaga profesional bertujuan untuk melaksanakan sistem pendidikan nasional dan mewujudkan tujuan pendidikan nasional. Seperti diamanatkan dalam Undang-undang Republik Indonesia no. 14 tahun 2005 tentang Guru dan Dosen pasal 10, dinyatakan bahwa kompetensi guru meliputi kompetensi paedagogik, kompetensi kepribadian, kompetensi sosial, dan kompetensi profesional yang diperoleh melalui pendidikan profesi. Dalam penjelasannya yang dimaksud kompetensi paedagogik adalah kemampuan guru mengelola pembelajaran peserta didik. Kompetensi kepribadian adalah kemampuan kepribadian yang mantap, berakhlak mulia, arif, dan berwibawa serta menjadi teladan peserta lain; yang dimaksud kompetensi profesional adalah kemampuan guru dalam penguasaan materi pembelajaran secara luas dan mendalam dan yang dimaksud dengan kompetensi sosial adalah kemampuan guru untuk berkomunikasi dan berinteraksi secara efektif dan efesien dengan peserta didik, sesama guru, orang tua/wali peserta didik dan masyarakat sekitar.

Didasarkan pada uraian diatas guru dituntut untuk memiliki komitmen, kemampuan keras dan kemampuan untuk melaksanakan pembelajaran sesuai dengan ketentuan tersebut diatas. Idealnya, proses pembelajarannya tidak hanya diarahkan pada upaya mendapatkan pengetahuan sebanyak-banyaknya, melainkan juga bagaimana menggunakan seluruh pengetahuan yang didapat tersebut untuk memecahkan permasalahan atau mengerjakan tugas yang ada kaitannya dengan bidang studi yang sedang dipelajari. Kemampuan untuk memecahkan masalah adalah sangat penting bagi siswa untuk masa depannya nanti. Siswa akan terlatih dan memiliki keterampilan untuk mengatasi masalah dan mengembangkan proyek yang dapat menghasilkan produk dan bertanggungjawab terhadap produk yang dibuat. Pengalaman tersebut akan sangat bermanfaat bagi siswa untuk mereka pelajari di dalam kelas dan dapat diterapkan dalam kehidupan nyata.

Kenyataan dalam pembelajaran yang terjadi selama ini adalah pembelajaran masih banyak yang tidak berhasil, tidak sesuai dengan apa yang menjadi harapan. Seperti yang penulis alami dalam pelaksanaan pembelajaran dengan materi "Memahami Makna Bersatu Dalam Keberagaman di Sekolah". Penulis menemukan kebanyakan siswa masih belum memahami materi, belum terampil dalam mengenal lembaga-lembaga negara dalam susunan pemerintahan tingkat pusat. Keterlibatan mereka dalam mengikuti pembelajaranpun juga sangat rendah. Hal itu ditandai dengan belum aktifnya siswa dalam mengikuti proses pembelajaran, mereka lebih asyik dengan kegiatannya sendiri.

Untuk meningkatkan prestasi, aktivitas, serta keterampilan belajar siswa, maka penulis bermaksud mengadakan perbaikan melalui Penelitian Tindakan Kelas (PTK). Penelitian ini dilaksanakan melalui dua siklus dan setiap siklusnya terdiri dari 4 rangkaian kegiatan yaitu perencanaan, pelaksanaan, pengamatan, dan refleksi. 


\section{METODE}

Model TPS atau berfikir, berpasangan, berbagi merupakan model struktural dalam pembelajaran kooperatif yang dirancang untuk mempengaruhi pola interaksi siswa. Model ini dikembangkan pertama kali oleh Frang Lyman dankoleganya di Universitas Maryland dari penelitian belajar kooperatif dan waktutunggu. Frang Lyman diacu dalam Irawati (2009), menyatakan bahwa model pembelajaran TPS merupakan suatu cara efektif untuk membuat variasi suasana pola diskusi kelas, dengan asumsi bahwa semua diskusi membutuhkan pengaturanuntuk mengendalikan kelas secara keseluruhan, dan prosedur yang digunakan.

Kelebihannya adalah dapat memberi siswa lebih banyak waktu berfikir, untuk merespon dan saling membantu.Menurut Trianto (2007) sintaks dalam pembelajaran TPS, yaitu:

a. Tahap 1, berpikir (think) yaitu: guru mengajukan pertanyaan di dalam kartu pembelajaran, yang berhubungan dengan pelajaran kemudian siswa dimintauntuk memikirkan jawaban pertanyaan tersebut secara mandiri.

b. Tahap 2, berpasangan (pair) yaitu: guru meminta siswa berpasangan dan berkelompok sesuai dengan kelompoknya untuk mendiskusikan jawaban pertanyaan yang telah dipikirkan pada tahap pertama. Interaksi pada tahap ini diharapkan dapat berbagi jawaban apabila telah diajukan suatu pertanyaan atau berbagi ide.

c. Tahap 3, berbagi (share) yaitu: guru meminta kepada masing-masing kelompok untuk berbagi, mempresentasikan hasil diskusi ke seluruh kelas. Ini efektif dilakukan dengan cara bergiliran pasangan demi pasangan dan dilanjutkan sampai sekitar seperempat pasangan telah mendapat kesempatan untuk melaporkan.

Adapun pelaksanaannya, yaitu:

1. Guru memberi apersepsi terlebih dahulu untuk mengajak siswa memasuki materi yang akan diajarkan.

2. Guru membagi siswa dalam kelompok kecil, dimana setiap kelompok terdiridari 4-6 siswa.

3. Setiap kelompok diberi kartu pembelajaran yang berisi gambar, klasifikasi,pertanyaan dan lembar jawab kartu pembelajaran.

4. Guru menyuruh siswa untuk memikirkan (think) jawaban yang ada di dalam kartu pembelajaran secara mandiri beberapa saat.

5. Guru menyuruh siswa untuk berpasang-pasangan (pair) dengan siswa lain sesuai dengan kelompoknya untuk mendiskusikan apa yang telah mereka pikirkan.

6. Guru menyuruh masing-masing kelompok untuk berbagi (share) mempresentasikan hasil diskusi kedepan kelas.

Pembelajaran TPS dapat memberikan keuntungan baik pada siswa kelompok atas maupun siswa kelompok bawah yang bekerja sama dalam menyelesaikan tugas. Siswa kelompok atas akan menjadi tutor bagi siswa kelompok bawah. Siswa memperoleh bantuan khusus dari teman sebaya yang mempunyai orientasi dan bahasa yang sama. Siswa kelompok atas juga akan meningkatkan kemampuan akademiknya karena memberi pelayanan sebagai tutor yang memerlukan pemikiran yang lebih mendalam tentang hubungan ide-ide yang terdapat pada materi tertentu. Interpersonal dan ketrampilan kelompok kecil yaitu guru harus memberikan kesempatan bagi anggota kelompok saling mengenal,menerima dan setiap dukungan lain, berkomunikasi secara akurat dan menyelesaikan perbedaan secara konstruktif (Zakaria 2007). Menurut Zeki (2010) pembelajaran TPS menunjukan bahwa bekerjasama dalam proses aplikasi kelompok dan juga antar kelompok memperkaya siswa dalam pembelajaran sain dan meningkatkan ketrampilan profesional mereka berdasarkan dokumen mereka berbagi pikiran, gagasan, asumsi dan keyakinan, memastikan saling mendukungdengan mengamati praktek satu sama lain dan merasa bahagia ketika mencapai sesuatu. Model TPS selain mempunyai keuntungan, juga mempunyai kelemahan. Kelemahannya adalah model TPS belum banyak diterapkan di 
sekolah, sangat memerlukan kemampuan dan ketrampilan guru, waktu pembelajaranberlangsung guru melakukan intervensi secara maksimal, menyusun bahan ajar setiap pertemuan dengan tingkat kesulitan yang sesuai dengan taraf berfikir anak dan, mengubah kebiasaan siswa belajar dari yang dengan cara mendengarkan ceramah diganti dengan belajar berfikir memecahkan masalah secara kelompok, hal ini merupakan kesulitan sendiri bagi siswa (Trianto).Model pembelajaran TPS mengakibatkan bertambah partisipasi siswa dan memahami konsep sama yang terungkap dari beberapa cara berbeda dari tiap individu berbeda. Hasil penelitian Zulfah (2006) tentang penggunaan model Think Pair Share ternyata dapat meningkatkan kualitas pembelajaran siswa pada materi pengolahan lingkungan. Hasil penelitian menunjukan bahwa ada peningkatan hasil belajar yang signifikan pada siswa yang diajarkan dengan menggunakan model TPS. Irawati (2009) juga melakukan penelitian menggunakan model TPS, dan hasil penelitian menunjukan penggunaan model TPS dapat meningkatkan hasil belajar yang signifikan pada siswa pada konsepsistem saraf.

\section{HASIL DAN PEMBAHASAN}

tHasil pelaksanaan dan pengamatan dari pra siklus, siklus I, dan siklus II oleh penulis sebagai pelaksana perbaikan pembelajaran dapat dicatat hal-hal sebagai berikut ;

1. Aktifitas Belajar Siswa

Penilaian aktivitas belajar siswa diperoleh berdasarkan prosentase jumlah siswa yang aktif mengikuti pembelajaran. Dengan pedoman pengamatan sebagai berikut :

Tabel 1. Jumlah siswa aktif

\begin{tabular}{cc}
\hline RENTANG BANYAKNYA SISWA & NILAI \\
AKTIF & 1 \\
$1-7$ & 2 \\
$8-14$ & 3 \\
$15-21$ & 4 \\
$22-28$ & 5 \\
$29-36$ & 5 \\
\hline
\end{tabular}

Penilaian Aktivitas belajar siswa dalam bentuk prosen dengan rumus : Prosentase $=$ Jumlah Nilai Perolehan X 100\% Nilai Maksimum

Keterangan :

$\begin{array}{ll}0-30 \%=\text { Kurang sekali } & 71 \%-85 \%=\text { Baik } \\ 31 \%-55 \%=\text { Kurang } & 86 \%-100 \%=\text { Baik Sekali }\end{array}$

$56 \%-70 \%=$ Cukup

Tabel 2. Rekapitulasi Aktivitas Belajar Siswa Pembelajaran Siklus I

\begin{tabular}{cccccc}
\multirow{2}{*}{ No. } & \multirow{2}{*}{ Kegiatan } & \multicolumn{3}{c}{ Nilai } & $\begin{array}{c}\text { Nilai } \\
\text { Perolehan }\end{array}$ \\
\cline { 3 - 5 } 1 & Menyimak & & v & & 3 \\
2 & Bertanya & & $\mathrm{v}$ & & 3 \\
3 & Mencatat & & & $\mathrm{v}$ & 4 \\
4 & Menjawab & & & & 3
\end{tabular}


5
68,00

Berdasarkan hasil observasi oleh guru pengamat dapat dijelaskan bahwa aktivitas belajar siswa pada pembelajaran pra siklus memperoleh hanya 52,00 prosen atau hanya 19 dari 36 siswa yang aktif dalam pembelajaran, ini menunjukkan nilai yang masih kurang. Pada pelaksanaan perbaikan pembelajaran siklus I, nilai aktivitas belajar siswa ada peningkatan dari 52,00 prosen menjadi 68,00 prosen atau dari 19 siswa menjadi 24 siswa ini baru menunjukan nilai cukup dalam aktivitas belajar

Tabel 3. Rekapitulasi Aktivitas Belajar Siswa Pembelajaran Siklus II

\begin{tabular}{|c|c|c|c|c|c|c|}
\hline \multirow{2}{*}{ No } & \multirow{2}{*}{ Kegiatan } & \multicolumn{4}{|c|}{ Nilai } & \multirow{2}{*}{ Nilai Perolehan } \\
\hline & & 12 & 3 & 4 & 5 & \\
\hline 1 & Menyimak & & & & v & 5 \\
\hline 2 & Bertanya & & $\mathrm{v}$ & & & 3 \\
\hline 3 & Mencatat & & & & v & 5 \\
\hline 4 & $\begin{array}{l}\text { Menjawab } \\
\text { pertanyaan }\end{array}$ & & $\mathrm{V}$ & & & 3 \\
\hline 5 & $\begin{array}{c}\text { Mengerjakan } \\
\text { Soal }\end{array}$ & & & & $v$ & 5 \\
\hline & Jumlał & Jilai & & & & 21 \\
\hline & Prese & & & & & 84,00 \\
\hline
\end{tabular}

Berdasarkan hasil observasi oleh guru pengamat dapat dijelaskan bahwa aktivitas belajar siswa pada pembelajaran siklus II, nilai aktivitas belajar siswa mengalami peningkatan sebesar $16 \%$ yaitu dari $68 \%$ menjadi $84 \%$ atau dari 24 siswa yang aktif pada pembelajran silklus I menjadi 30 siswa pada pembelajaran siklus II. Nilai 84 prosen menunjukan aktivitas belajar yang baik .

\section{SIMPULAN}

Berdasarkan beberapa penjelasan baik data maupun informasi hasil penelitian yang telah dipaparkan di depan maka dapat disimpulkan bahwa perbaikan pembelajaran yang telah dilaksanakan sebanyak dua siklus mata pelajaran Pendidikan Kewarganegaraan dengan materi " makna bersatu dalam keberagaman disekolah" di Kelas II SD Negeri Luwunggede 03 Kecamatan Larangan Kabupaten Brebes telah berhasil.Keberhasilan tersebut dapat dijelaskan secara rinci sebagai berikut :

1. Penggunaan metode diskusi dengan model pembelajaran Think Pair Share (TPS) dapat meningkatkan aktifitas belajar siswa Kelas II SD Negeri Luwunggede 03 Kecamatan Larangan Kabupaten Brebes pada materi mengenal makna bersatu dalam keberagaman disekolah yaitu pada pembelajaran pra siklus rata-rata aktivitas siswa hanya $52,00 \%$, pada pelaksanaan perbaikan pembelajaran siklus I naik menjadi $68,00 \%$. Kemudian pada pelaksanaan pembelajaran siklus II berhasil meningkat menjadi 84,00\%.

2. Penggunaan metode diskusi dengan model pembelajaran Think Pair Share (TPS) dapat meningkatkan Prestasi belajar siswa Kelas II SD Negeri Luwunggede 03 
Kecamatan Larangan Kabupaten Brebes pada materi mengenal makna bersatu dalam keberagaman disekolah.terbukti pada pembelajaran pra siklus rata-rata prestasi belajar siswa hanya 56,11 , kemudian pada perbaikan pembelajaran siklus I meningkat menjadi 65,00 dan pada pembelajaran siklus II mengalami keberhasilan, rata-rata nilai menjadi 75,00 .

Keberhasilan ini karena guru telah menggunakan berbagai aktivitas yang mengaktifkan siswa, yaitu penggunaan model pembelajaran Think Pair Share (TPS) melalui metode diskusi kelompok dengan media gambar makna bersatu dalam keberagaman disekolah.

\section{DAFTAR PUSTAKA}

D. Setiawan, dkk , (2008). Komputer dan Media Pembelajaran. Jakarta: Universitas Terbuka.

Kusumawardani, A.Sunarso, (2006). Pendidikan Kewarganegaraan untuk SD dan MI Kelas IV. Surakarta: Grahadi ( Hal. 34-37)

M.S,Thayeb, (2006). Pendidikan Kewarganegaraan untuk SD Kelas II. Jakarta: Erlangga ( Hal. 55-58)

Muhsetyo, Gatot, dkk (2008). Pembelajaran Matematika SD. Jakarta: Universitas Terbuka

Rochiati Wiriaatmadja (2008). Metode Penelitian Tindakan Kelas untuk meningkatkan kinerja guru dan dosen. Bandung: Remaja Rosdakarya.

Septriana dan Handoyo. (2007). Penerapan Think-Pair-Share Dalam Pembelajaran Kooperatif Untuk Meningkatkan Prestasi Belajar Geografi. Jurnal Pendidikan IImiah, 1(1):14-11.

Tita Lestari (2009). Materi Pendampingan KTSP Supervisi Akademik Pembelajaran, Semarang: Unnes.

Wahyudini, D, Supriadi, Abdulhak, I. (2000). Pengantar Pendidikan. Jakarta: Universitas Terbuka.

Wibawa,B,Dr, (2003). Penelitian Tindakan Kelas. Jakarta: Departemen Pendidikan Nasional

Winataputra, U, dkk, (2004). Strategi Belajar Mengajar. Jakarta: Universitas Terbuka.

Winataputra, U, dkk, (2007). Teori Belajar dan Pembelajaran. Jakarta: Universitas Terbuka.

Winataputra, U, dkk, (2007). Materi dan Pembelajaran PPKn SD. Jakarta: Universitas Terbuka.

Zaenul, A\&Mulyana, A (2004). Tes dan Asessmen di SD. Jakarta: Universitas Terbuka. 